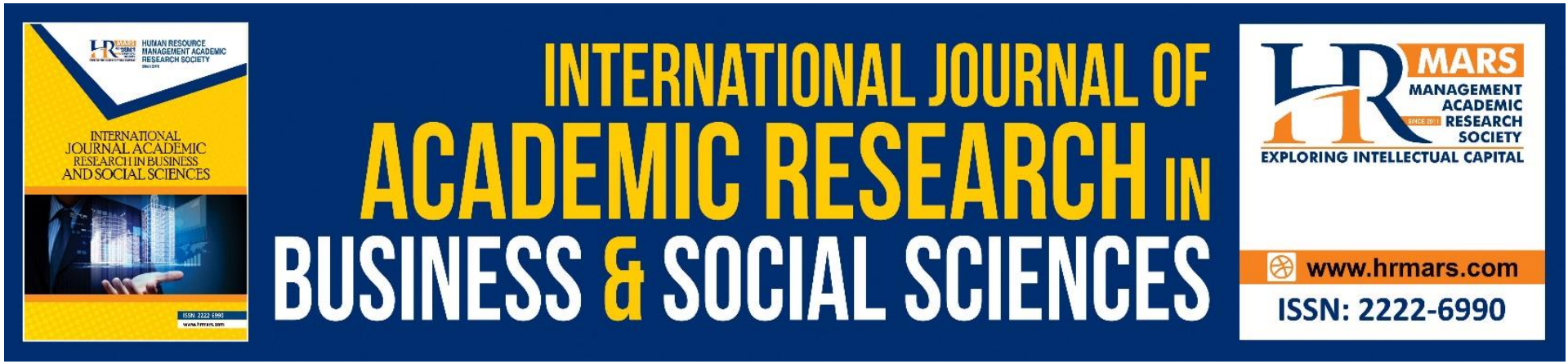

\title{
Use of Supply Chain Risk Management Approach for Achieving Firms' Performance
}

Catherine W. Munyi, Gregory S. Namusonge, Alice Simiyu

To Link this Article: http://dx.doi.org/10.6007/IJARBSS/v10-i12/8376 DOI:10.6007/IJARBSS/v10-i12/8376

Received: 13 October 2020, Revised: 17 November 2020, Accepted: 29 November 2020

Published Online: 16 December 2020

In-Text Citation: (Munyi et al., 2020)

To Cite this Article: Munyi, C. W., Namusonge, G. S., \& Simiyu, A. (2020). Use of Supply Chain Risk Management Approach for Achieving Firms' Performance. International Journal of Academic Research in Business and Social Sciences, 10(12), 888-896.

\section{Copyright: (c) 2020 The Author(s)}

Published by Human Resource Management Academic Research Society (www.hrmars.com)

This article is published under the Creative Commons Attribution (CC BY 4.0) license. Anyone may reproduce, distribute, translate and create derivative works of this article (for both commercial and non-commercial purposes), subject to full attribution to the original publication and authors. The full terms of this license may be seen at: http://creativecommons.org/licences/by/4.0/legalcode

Vol. 10, No. 12, 2020, Pg. 888 - 896

Full Terms \& Conditions of access and use can be found at http://hrmars.com/index.php/pages/detail/publication-ethics 


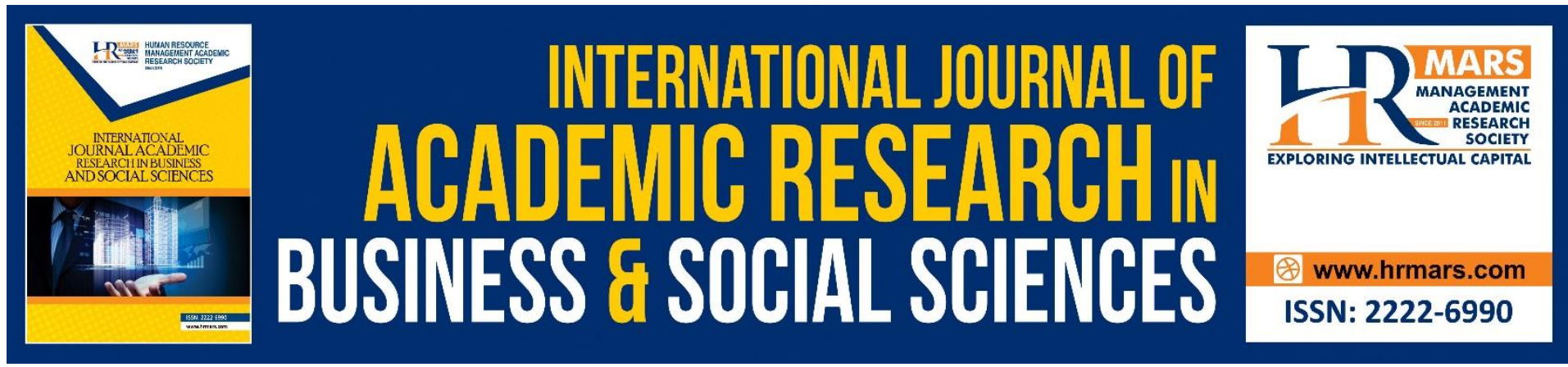

\title{
Use of Supply Chain Risk Management Approach for Achieving Firms' Performance
}

\author{
Catherine W. Munyi (PhD Candidate) \\ Department of Procurement and Logistics, Jomo Kenyatta University of Agriculture and \\ Technology, Kenya
}

Gregory S. Namusonge

School of Entrepreneurship, Procurement and Management, Jomo Kenyatta University of Agriculture and Technology, Kenya

Alice Simiyu

Department of Procurement and Logistics, Jomo Kenyatta University of Agriculture and

Technology, Kenya

\begin{abstract}
Purpose -The purpose of this paper is to examine effectiveness use of supply chain risk management approach for achieving firms' performance.

Design/Methodology/Approach- A cross-sectional approach was adopted with primary data collected. The data yielded a response rate of 375 from electricity firms in Kenya. The data collected were put through rigorous statistical analysis to test content validity as well as reliability. Further, simple linear regression model was used to test relationships between strategic sourcing and firm's performance.

Findings- The finding proposes that a successful execution of supply chain risk management (SCRM) increases organizational performance through regular risk assessment and training of all stakeholders. Further, the paper reveals that majority of electricity firms were reluctant in sharing supply chain risk information.

Research limitations/implications-The study provides managers with insightful understanding and the application of SCRM for achieving firm' performance. Also, the study show that supply chain risk management generally increases the performance of electricity firms but not all SCRM approaches are covered in the study and therefore a similar study can done in different sector to validate the findings.

Originality/Value The study provides a holistic approach in the application and use of SCRM for achieving firms' performance. Also, the identified gaps provides future direction in research and encourage new techniques for combating SCRM for achieving firm' performance.
\end{abstract}

Keywords: Supply Chain Risk Management, Supply Chain Risk Management Approaches, Performance of Electricity Firms in Kenya, Simple Regression 


\section{Introduction}

Today markets have become very dynamic, and customers are demanding more variety, better quality, low prices, higher reliability, highly responsiveness and faster delivery of goods and services. Supply chains have become more susceptible to unpredictable events that could lead to supply disruptions and undermine supply chain performance (Kihyun, 2012). According to Giunipero and Eltantawy (2004), they observed that supply chain risks comprises any risks for the information, material and product flows from original supplier to the delivery of the final product for the end user. While according to Christopher and Lee (2001), not that risks may comprise of the environmental, organizational or supply chain-related variables which cannot be predicted with certainty and which impact on the supply chain outcome. Ouabouch and Pache (2014) suggested that there are three different sources of uncertainty that plague supply chains and they include, supplier uncertainty, arising from on-time performance, average lateness, and degree of inconsistency; manufacturing uncertainty, arising from process performance, machine breakdown, supply chain performance; and customer or demand uncertainty, arising from forecasting errors and irregular orders. Thus, risk consequences are the focused supply chain outcome such as costs or quality (Hendrics \& Singhal, 2005), hence the need for supply chain risk management.

This paper is structured as follows. In section 2, we present how supply chain risk management interacts with the firm's performance from the literature reviewed. Part 3 discusses research methodology. Section 4 statistical analysis of data collected and part 5 presents the conclusions both discussion and implications.

\section{Literature Review}

Supply Chain Risk Management

Risk can be defined as the probability of variation surrounding an anticipated outcome (Wiseman \& Gomez-Mejia, 1998). Zsidisin et al. (2010) define supply chain risk as the potential occurrence of an inbound supply incident which leads to the inability to meet customer demand. Risk management is a continual process that involves long-term dedication of supply chain members (Zsidisin et al., 2010; Khalid, 2020). Supply chain risk management is assumed to either proactively mitigate or reactively respond to risks (Tomlin, 2006; Ghagde, Dani \& Kalawsky, 2013). The conceptualization of supply chain risk management incorporates supply chain resilience and supply chain vulnerability (Sorensen, 2005). According to Ponomarov and Holcomb (2009), supply chain resilience is an important part of SCRM. Supply chain resilience means the capability of companies to anticipate, identify, react and learn from incidents (Craighead, Blackhurst, Rungtusanatham, \& Handfield, 2007; Sheffi, 2006). Christopher (2005) stated that resilient processes are agile and are able to change quickly. The adaptive nature of capability allows the supply chain to recover after being disrupted, returning to its original state or achieving a more desirable state of supply chain operations (Murigi, 2013). Conceptualization of a resilient supply chain includes elements such a supply base strategy, collaborative planning, visibility, and developing supply chain resilient culture considerations into decisions (Arani 2015). Peck (2005) defined supply chain vulnerability as exposure to serious disturbance arising from risks within and external to the chain. Antonette et al. (2002) described supply chain vulnerability as the tendency of risk sources and risk drivers outweighing risk mitigating strategies, thus causing adverse supply chain consequences. Supply chain consequences can cause significant detrimental effects on supply chain, with a cascading effect through the supply chain to final consumers since each link within a supply chain is dependent on the other links to meet product or 
service requirements (Papadakis, 2006). According to Waters (2007), vulnerability reflects the susceptibility of a supply chain to disruption, and is a consequence of risks in it. Supply chain risk management aims at identifying the potential sources of risk and implementing appropriate actions to avoid or contain supply chain vulnerability (Svensson, 2002). Supply chain risk management can therefore be defined as the identification and management of risks for the supply chain, through a coordinated approach amongst supply chain members, to reduce supply chain vulnerability as a whole (Kern, Moser, Hartmann \& Moder, 2012).

In order to manage risk effectively, organisations are moving to adopt closer relationships with key players in the chain (Chen, et al., 2013). Some of the strategies organisations are using to expand their power and manage the risk of uncertainty include; mergers and alliances (Kilubi \& Haasis,2015); the use of e-procurement to integrate supply chains leading to reduced transaction costs (Antonette et al., 2002); and collaborative supply management which increase product reliability and reduces risks in product introduction (Chen, Sahol \& Prajogo, 2013). According to Hewlett Packard (2006) Supply chain risk management can occur through contingency planning and by building more resilient and agile supply chains (Ngugi, 2013). It has been suggested by Ponomarov (2012) and Yang and Yang (2012) that any approach to managing risks in the supply chain should adopt cross company supply chain orientation. For electricity sub-sector it is crucial to manage risks that leads to delays in electricity connection, high costs and disruption in power supply due to vandalism of equipment.

\section{Performance of Firms Measurement}

Performance measure entails both quantitative and qualitative assessment of the degree to which a firm achieves the general or specific objectives (Lysons \& Gillingham, 2003). Traditional performance measures of firms is based on financial indicators such as profit, market share and cost. Performance measures in supply chain range from cost and non-cost measures (Lunga \& Mbanje, 2015), financial and business process perspectives (Chopra \& Meindl, 2010), to customer satisfaction, revenues, as well as learning and growth (Taghipour, Bagheri, Khodarezaei \& Farid, 2015), as well as operational measures such as quality performance or cycle time (Sherman, 2001). Performance measure within the firm is used in several ways including forming a basis for; evaluation and reward of individuals, allocation of scarce resources among strategic business units, and making decisions that increase future profitability (Chan \& Qi, 2006). It is therefore essential for firms to consider the nature of SCM practices that influence the supply chain performance. A well-designed performance measurement system is central in understanding and improving the performance of all the actors in the supply chain operations (Chan \& Qi, 2006). However nowadays, both financial and non-financial indicators such as quality, delivery time, lead times, customer satisfaction among others, form the basis for performance measurement. In this study, both financial and non-financial indicators are used to measure the firms' performance, such as revenue generation and customer satisfaction. This lead to the following research hypothesis;

$\mathrm{HO}_{1}$ : Supply chain risk management has no significant influence on the performance of electricity firms in Kenya

\section{Methodology}

Instrument Development

Content validity is ensured by adapting all the instruments from the existing previous researches in strategic sourcing, which are deemed to have reliable and valid scales. A five- 
point Likert scale anchored by 1 (Strongly Disagree) 5 (Strongly agree) is used to assess the degree of strategic sourcing in the opinion statements provided "kindly assess to what extent you agree or disagree with the following opinion statement'. Firms performance was also measured using a five-point Likert scale of 1 (Strongly Disagree) 5(Strongly Agree) and by ticking in the box of the revenue indicators provided for the last five years.

\section{Data Collection}

The study focused on electricity firms in Kenya because few studies are featured in this sector. The study targeted logistics/supply chain/procurement managers in senior positions to answer the dropped questionnaires since they possessed sufficient knowledge regarding the overall process of strategic sourcing and firms' performance. After randomly selecting 375 samples of respondents, the researchers dropped the questionnaires which generated later a response rate of 317 .

\section{Results}

The following section contains the findings of strategic sourcing and firms' performance in the descriptive and inferential statistics form. The respondents were asked to indicate the extent to which they agreed with supply chain risk practice opinion statements that are executed in the electricity firms in Kenya. The results of the analysis are presented in Table 4.1. From the findings, majority of the respondents agreed that electricity firms carry out assessment of risks regularly within electricity supply chain and stakeholders are regularly trained on risk management and was highly rated with a mean of 3.996 and 3.845 and a standard deviation of 1.140 and 1.132 respectively. However majority of the respondents were undecided as to whether electricity firms share supply chain risk information with partners and was rated as neutral with a mean of 3.110 and a standard deviation of 1.342 .

Table 4.1: Supply chain risk management Descriptive Statistics analysis

\begin{tabular}{|c|c|c|c|c|c|c|c|}
\hline Opinion statement & $\begin{array}{l}\text { SA } \\
(\%)\end{array}$ & $\begin{array}{l}A \\
(\%)\end{array}$ & $\begin{array}{l}\text { UN } \\
(\%)\end{array}$ & $\begin{array}{c}D \\
(\%)\end{array}$ & $\begin{array}{l}\text { SD } \\
(\%)\end{array}$ & Mean & $\begin{array}{c}\text { Std. } \\
\text { Deviation }\end{array}$ \\
\hline $\begin{array}{l}\text { 1. The organisation carries } \\
\text { out assessment of risks } \\
\text { regularly within electricity } \\
\text { supply chain }\end{array}$ & 42.0 & 30.9 & 19.6 & 0.0 & 7.6 & 3.996 & 1.140 \\
\hline $\begin{array}{l}\text { 2. The organisations } \\
\text { stakeholders are regularly } \\
\text { trained on risk } \\
\text { management }\end{array}$ & 30.6 & 42.6 & 15.1 & 4.1 & 7.6 & 3.845 & 1.132 \\
\hline $\begin{array}{l}\text { 3. Organisations within } \\
\text { electricity supply chain } \\
\text { share risk information with } \\
\text { partners. }\end{array}$ & 23.0 & 11.4 & 34.7 & 15.5 & 15.5 & 3.110 & 1.342 \\
\hline
\end{tabular}

An additional test was conducted on simple regression to determine the influence of supply chain risk management on the performance of electricity firms in Kenya. The model used was $Y=\beta_{0}+\beta_{1} \mathbf{X}_{1}+\varepsilon$. Where: $Y=$ Performance of electricity sub-sector supply chain $\beta_{0}=$ constant 
(Slope) of the Model $\beta_{1}$ is the coefficient for $X_{1} ; X_{1}=$ supply chain risk management practice; $\varepsilon$ = error term

The null hypothesis was

$\mathrm{HO}_{1}$ : Supply chain risk management has no significant influence on the performance of electricity firms in Kenya.

The study tested the hypothesis by use of linear regression which tested the relationship between supply chain risk management and performance of electricity firms in Kenya. Path coefficients determined the direction and strength while T statistics provided information on the significance to the relationships. Table 4.2 presents the results.

Table 4.2 Model Summary of Supply Chain Risk Management

\begin{tabular}{|c|c|c|c|c|c|}
\hline Model & $R$ & R Square & $\begin{array}{c}\text { Adjusted R } \\
\text { Square }\end{array}$ & $\begin{array}{c}\text { Std. Error of the } \\
\text { Estimate }\end{array}$ & Durbin-Watson \\
\hline 1 & $.141^{a}$ & .120 & .107 & 3.03378 & 1.868 \\
\hline
\end{tabular}

The $\mathrm{R}^{2}$ for the regression model between supply chain risk management and performance of electricity firms in Kenya was 0.107 meaning that supply chain risk management explains 10.7 $\%$ variation in the performance of electricity firms in Kenya while the remaining variation is explained by other factors not considered in this study. The regression model was a good fit as indicated by a significant Fstatistic $(F=6.376, p<0.05)$. See Table 4.3.

Table 4.3 ANOVA of Supply Chain Risk Management

\begin{tabular}{rlrrrrr}
\hline Model & & Sum of & df & \multicolumn{1}{c}{$\begin{array}{c}\text { Mean } \\
\text { Square }\end{array}$} & F & Sig. \\
& & Squares & & & \\
\hline \multirow{2}{*}{1} & Regression & 58.686 & 1 & 58.686 & 6.376 & $.012^{\mathrm{b}}$ \\
& Residual & 2899.194 & 315 & 9.204 & & \\
\cline { 2 - 6 } & Total & 2957.880 & 316 & & & \\
\hline
\end{tabular}

a. Dependent Variable: Performance of electricity firms in Kenya

b. Predictors: (Constant), Supply chain risk management

The regression model obtained from the output was

Performance $=11.102+0.227$ supply chain risk management + error

The regression coefficient for supply chain risk management was 0.141 . This indicated that a unit increase in the supply chain risk management would result in $14.1 \%$ increase in the performance of electricity firms in Kenya. The t-statistic for the regression coefficient for supply chain risk management was significant at $5 \%$ level of significance $(T=10.757, p<0.05)$ implying rejection of null hypothesis.See Table 4.4. On the basis of these statistics, the study concludes that there is significant positive relationship between supply chain risk management and performance of electricity firms in Kenya. 
Table 4.4 Coefficients of supply chain risk management

\begin{tabular}{lrrrrr}
\hline Model & \multicolumn{2}{c}{$\begin{array}{c}\text { Unstandardized } \\
\text { Coefficients }\end{array}$} & $\begin{array}{c}\text { Standardized } \\
\text { Coefficients } \\
\text { Beta }\end{array}$ & t & Sig. \\
& B & Std. Error & & & \\
\hline (Constant) & 11.102 & 1.032 & & 10.757 .000 \\
1 Supply chain risk & .227 & .090 & & .141 & 2.525 .012 \\
management & & & & & \\
\hline
\end{tabular}

a. Dependent Variable: Performance of electricity firms in Kenya

\section{Discussion}

Theoretical Contribution

The study contributes to the understanding of the association between supply chain risk management and firm's performance. From the study findings, it was found out that electricity firms carry out assessment of risks regularly within electricity supply chain. This finding was in agreement with a study carried out by Kern, Moser, Hartmann and Moder (2012) who asserted that supply chain risk management entails identification and management of risks for the supply chain, through a coordinated approach amongst supply chain members, to reduce supply chain vulnerability as a whole. It was also found from the study that electricity firms' stakeholders are regularly trained on risk management. This result agreed with the study by Blackhurst et al. (2011); Rice and Caniato (2003), who noted that companies provide training to employees, suppliers and customers about security and supply network risks raising awareness and reinforcing the importance of supply chain resilience.

Sharing of risk information with partners within electricity firms supply chain was rated as neutral with a mean of 3.110 and a SD of 1.342. This finding concurred with a study by Adem (2014), which revealed that adoption of capacity reservation contracts and suppliers' disruption historical background checks had not been taken seriously by power sector firms in Kenya leading to supply chain disruptions. Ponomarov and Holcomb (2009) assert that "risk assessment and sharing among the members of a supply chain is an essential element of risk mitigation". Supply chain partners must share a common understandings and awareness of the risks that could occur within their operations (Faisal et al., 2006).

\section{Conclusions and Recommendations}

The study concludes that majority of electricity firms' operational activities have been hampered by a number of activities such as demand changes, plans alterations, changes in time scheduled for activities and sometimes operations are affected by policy changes. Also, the study concludes that majority of electricity firms carried out assessment of risks regularly within electricity supply chain. Likewise, the study concludes that majority of electricity firms' stakeholders are regularly trained on risk management issues however they are reluctant in sharing supply chain risk information regularly. Similarly, the study concludes that supply chain risk management influence positively the performance of electricity firms in Kenya. Thus supply chain risk management was significant at $5 \%$ level of significance and the null hypothesis $\left(\mathrm{H}_{1}\right)$ was rejected.

Therefore, the study recommends that electricity firms management should be aware of risks such demand changes, sudden plan alterations, changes in time schedule which affect their operations negatively on day to day basis. These risks were found to affect the operations of electricity firms in the study. Also, the study recommends to the management of electricity 
firms that they should carry out assessment of risks regularly within electricity supply chain and train workers regularly. This would enable them to prepare and mitigate any risks that they are likely to suffer. The study also recommends the management to consider sharing of supply chain risks information with other partners so as to mitigate or avoid some risks along the chain. Similarly, the study recommends to the management of electricity firms that they incorporate supply chain risk management in their policy statement because from the study it was established that supply chain risk management influence positively the performance of electricity firms in Kenya.

\section{Limitations and Future Research}

The study provides managers with insightful understanding and the application of SCRM for achieving firm' performance. Also, the study show that supply chain risk management generally increases the performance of electricity firms but not all SCRM approaches are covered in the study and therefore a similar study can done in different sector to validate the findings.

\section{References}

Arani, W., Mukuru, E., Waiganjo, E., \& Musyoka, J. (2015). Enhancers for building supply chain resiliencein manufacturing firms in kenya. The strategic journal of business and change management, 2(71), 709-749.

Blackhurst, J., Dunn, K., \& Craighead, C. (2007). An empirically derived framework of global supply resiliency. Journal of Business Logistics, 32(4), 374-391.

Chan, F., \& Qi, H. (2006). An innovative performance measurement method for supply chain management. Supply chain management. An International Journal, 8(3), 209-223.

Chopra, S., \& Meindl, P. (2010). Supply Chain Management: Strategy, Planning, and Operation (6 ed.).

Ghadge, A., Dani, S., Chester, M., \& Kalawsky, R. (2013). A systems approach for modeling supply chain risks. Supply Chain Management. An International Journal, 523-538.

Giunipero, L., \& Eltantawy, R. (2012). Securing the upstream supply chain: A risk management approach. International Journal of Physical Distribution \& Logistics Mnagement, 698713.

Hendricks, K. (2005). The Effect of Supply Chain Glitches on Shareholder Wealth. Journal of Operations Management, 21(5), 501-22.

Khalid, N. (2020). Artificial intelligence learning and entrepreneurial performance among university students: evidence from malaysian higher educational institutions. Journal of Intelligent \& Fuzzy Systems, (Preprint), 1-19.

Kilubi, I., \& Haasis, H. (2015). Supply chain risk management enablers- A framework development through systematic review of literature from 2000-2015. International journal of business and applied management, 10(1), 35-54.

Lysons, B., \& Farington, B. (2003). Purchasing and supply chain management. Harlow Essex: Prentice Hall.

Ponomarov, S., \& Holcomb, M. (2009). Understanding the concept of supply chain resilience. The International Journal of Logistics Management, 20(1), 124-143.

Waters, D. (2007). Supply chain risk management: Vulnerability and resilience in logistics. London: Kogan Page Limited. 
INTERNATIONAL JOURNAL OF ACADEMIC RESEARCH IN BUSINESS AND SOCIAL SCIENCES Vol. 10 , No. 12, 2020, E-ISSN: 2222-6990 @ 2020 HRMARS

Zsidisin, G. A., \& Wagner, S. M. (2010). Do perceptions become reality? The moderating role of supply chain resiliency on disruption occurrence. Journal of Business Logistics, 31(2), 1-20. 